\title{
Bacterial Profile and Antimicrobial Susceptibility in Neonatal sepses, Al - Alwyia Pediatric Teaching Hospital in Baghdad
}

\author{
Tareef Fadhil Raham*; Assad Muhsen Abood ${ }^{* *}$ :Abd Saad Amin ${ }^{* * *}$; Amal Mahmood Shaker***; Salwa Joseph \\ Saleem ${ }^{* * * ; N a s s e r a h ~ A t t i a ~ T h a b e t ~}{ }^{* * * *}$; Senaa Jalil Esmail ${ }^{* \star *}$
}

\begin{abstract}
Background: Neonatal septicemia is a major health problem in developing countries furthermore data on bacteriological profile in early onst sepses (EOS) and late neonatal sepsis (LOS) are lacking in context of continuous change in bacteriological profile and increasing resistant strains. Objectives: The study done to determine the pattern of organisms implicated in neonatal septicemia in a neonatal care unit and to measure the degree of bacterial resistance to some antibiotics.

Type of the study : cross -sectional study.

Methods: Confirmed cases of neonatal septicemia admitted at Al-Alwyia pediatric teaching hospital for the period from January 2011- January 2012 were included which constitute 107 case. Blood samples were obtained, incubated and Subculture was done on blood agar and MacConkey Agar routinely after 48 hours and 7 days and in between if visible turbidity appeared. Bacterial isolates and antibiotic sensitivity were identified by standard conventional methods.
\end{abstract}

Results EOS constituted 29.9\%(32 case) of confirmed neonatal sepsis, while LOS constituted $70.1 \%$ (75case) .Eescehrichia coli (E. coli) constitutes $37 \%$ of EOS followed by Klebsella pneumonia and Staphylocoocus species (which constitute $12.5 \%$ for each of them ) were the most common microorganisms, while for LOS: E.coli constituted $38.7 \%$ of LOS followed by Staphylocoocus species $17.3 \%$ and Klebsella pneumonia 10.7\%. Gram negative (G negative) bacteria predominated over gram positive (G positive) bacteria in both EOS (81.2\%) and LOS (74.7\%) . Staphylocoocus species predominates $G$ positive sepsis in both EOS and LOS. Group B streptococci are not identified in the study sample. Microorganisms tested shows highly resistant to amoxicillin or ampicillin and to gentamycin.For amoxicillin or ampicillin higher resistant (100\%) were encourted with pseudomonas, proteus and Enterobacter. For cefotaxime high rate of resistance encountered with klebsella (71.4\%) compared to $40 \%$ resistant in pseudomonas. Amikacin also shows varied degree of resistant for E. coli(22\% ) and klebsella (41\%) , pseudomonas(10\%) ,and Enterobacter (16.7\%) .for Staphylococcus aureus, proteus and citrobacter no resistance was encountered to amikacin and the sensitivity was $100 \%$ in tested isolates .

Conclusions: G negative bacteria is more common in EOS and LOS with predominant of $E$. coli in two categories .Resistant strains to commonly used antibiotics is a common finding. Guidelines in treatment of neonatal sepsis should be frequently reviewed taking in consideration antimicrobial resistance. Due to magnitude of problem, preventive measures for EOS and LOS should be considered.

Key words: Early onset sepsis (EOS), Late onset sepsis (LOS), Neonatal Sepsis, antimicrobial resestance

\section{Al-Kindy College Medical Journal 2017: Vol. 13 No.2 Page: 21-25}

${ }^{*} \mathrm{DCH}$; CABP Pediatric Consultant Al Alwyia Pediatric Teaching Hospital

** Pediatrician specialist at Alwyia PediatricTeaching Hospital

*** MA degree bacteriology, $\mathrm{MOH}$ Iraq, Bactriologist at Al Alwyia Pediatric Hospital

$* * * *$ Bacteriology specialist $\mathrm{MOH}$

Received $1^{\text {th }}$ June 2016, accepted in final $12^{\text {th }}$ January 2017

Corresponding to Tareef Fadhil Raham, email: tareeffadhil@yahoo.com

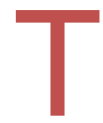
he incidence of neonatal sepsis is 1-4 per 1000 live births in developed countries[1] while in developing countries, the incidence of neonatal sepsis is about 3.5-4.3 cases per 1000 live births[2]. Neonatal sepsis may be categorized as early onset sepsis (EOS) presenting in first 72 hours of life or late-onset (LOS) presenting after 72 hours of life. EOS is associated with acquisition of microorganisms from the maternal birth canal. Transplacental infection or an ascending infection from the cervix may be caused by organisms that colonize the mother's genitourinary tract; the neonate acquires the microorganisms as it passes through the colonized birth canal at delivery as in EOS or is acquired from the care giving environment as in LOS [3,4]. A very wide spectrum of organisms has been described for cases of neonatal septicemia and this spectrum is subjected to geographical alterations Moreover, the isolated organisms are often resistant to multiple antimicrobials which make the treatment difficult and grave sequele ensue [5]. The choice of antibiotics treatment for neonatal sepsis must be driven by hospital -specific guidelines based on prevalent organisms and their susceptibility patterns in the particular nursery/hospital environments [6] Historical reviews have also demonstrated that the predominant organisms responsible for neonatal sepsis have changed with time[7]. In context of changing microorganism profile worldwide and scarce of data (locally) regarding causative microorganisms in neonatal unit (NNU) and the microorganisms' sensitivity to antibiotics this study 
is done to reveal current profile in neonatal word in Alalwyia pediatric teaching hospital in Baghdad and to reveal bacteriological susceptibility for antibiotics.

Methods: All confirmed cases of neonatal septicemia diagnosed and treated in the neonatal unit at al-Alwyia pediatric teaching hospital for the period from January 2011- January 2012 were included in this study which constitute 107 cases. A case of sepsis was defined as an infant who had clinical signs of infection or those who were born to mothers with risk factors for infection, in whom blood culture grew a bacterial pathogen.EOS include all cases presented during 72 hours of life while LOS after 72 hours of life till 28 days of life .Neonatal period constitute the first 28 days of life Blood cultures were collected before starting antibiotics from all neonates with risk factors of sepsis and whenever relevant clinical signs were present. Blood samples were obtained under strict aseptic conditions. The skin site was cleansed with $70 \%$ alcohol and povidone iodine (1\%) followed by $70 \%$ alcohol again. One- to two-mililiter blood samples were withdrawn and injected in aerobic broth bottles then incubated at $37^{\circ} \mathrm{C}$ for 7 days and observed daily for any turbidity due to bacterial growth. Subculture was done on blood agar and MacConkey Agar routinely after 48 hours and 7 days. Subculture was also done in between if visible turbidity appeared. Bacterial isolates were identified by conventional biochemical and serological methods. Antimicrobial susceptibility test was performed using the standard disc diffusion (Kirbey-Bauer) method.
Results: A total number of 107 blood culture confirmed cases were studied. As shown in table 1 ,EOS constitute $29.9 \%$ of overall septicemia (32cases) ,while LOS constitute $70.1 \%$ (75 cases).In order of frequency the study shows that microorganisms causing EOS are :E.coli accounts $12(37 \%$ of EOS ) followed by Klebsella pneumonia and Staph species (pp.) 4(12.5\%) ,Pseudomonas pp. and Acinetobacter pp. 3(9.4\%) for each , Proteius and Citrobacter $p p$. 2(6.2\%)for each, Enterococcus pp. and candida $13.1 \%$ )for each.In order of frequency the study shows that microorganisms causing LOS are :E.coli accounts 29(38.7 of LOS ), Staphylococcus pp. 13(17.3\%) ,Klebsella pneumonia 8(10.7), Pseudomonas pp. and Enterobacter cloacae 7(9.3\%) for each , Acinetobacter pp. 4(5.3\%) ,Strep pneumonia, Citrobacter pp. and candida1(1.3\%)for each of them. Overall isolated cases the 3 most common microorganisms are Ecoli 41 (38.3\%), Staphylococcus pp. $17(15.9 \%)$ and klebsella pneumoni $12(11.2 \%)$.No isolates were found for group B streptococcus, Haemophilus influenza and listeria in both EOS and LOS. G negative Bacteria predominates in both EOS(24.3\% for $G$ negative vs $4.7 \%$ for $G$ positive bacteria ) and LOS(52.3\% for G negative vs $16.8 \%$ for $\mathrm{G}$ positive) . E.coli is the most common $\mathrm{G}$ negative bacteria encountered in EOS and LOS. Staph species. is the most common $G$ positive bacteria encountered in EOS and LOS .

Table 1 : Bacteriological profile of EOS and LOS

\begin{tabular}{|c|c|c|c|}
\hline Type of bacteria & $\begin{array}{c}\text { No. of EOS } \\
\text { ( \%within total ) } \\
\text { (\% within EOS) }\end{array}$ & $\begin{array}{c}\text { No.of LOS } \\
\text { ( \%within total ) } \\
\text { (\% within LOS) }\end{array}$ & Total no.(\%) \\
\hline \multicolumn{4}{|c|}{ A-G Negative Bacteria } \\
\hline E.coli & $12(11.2)(37.5)$ & $29(27.1)(38.7)$ & $41(38.3)$ \\
\hline Klebsella pneumonia & $4(3.7)((12.5)$ & $8(7.5)(10.7)$ & $12(11.2)$ \\
\hline \multicolumn{4}{|l|}{ Pseudomonas species } \\
\hline Pseudomonas Fluorescent & $1(0.9)$ & 0 & $1(0.9)$ \\
\hline Pseudomonas putida & 0 & $1(0.9)(1.3)$ & $1(0.9)$ \\
\hline Pseudomonas stutzeri & $1(0.9)(6.2)$ & 0 & $1(0.9)$ \\
\hline Pseudomonas aerogenosa & $1(0.9)(6.2)$ & $6(5.6)(8)$ & $7(6.5)$ \\
\hline Pseudomonas Total & $3(2.8)(9.4$ & $7(6.5)(9.3)$ & $10(0.9)$ \\
\hline Proteius & $2(1.9)(6.2)$ & 0 & $2(1.9)$ \\
\hline Enterobacter cloacae & 0 & $7(6.5)(9.3)$ & $7(6.5)$ \\
\hline \multicolumn{4}{|l|}{ Citrobacter species } \\
\hline Citrobacter cloaca & $2(1.9)(6.2)$ & 0 & $2(1.9)$ \\
\hline Citrobacter fruendi & 0 & $1(0.9)(1.3)$ & $1(0.9)$ \\
\hline Citrobacter Total & $2(1.9)(6.2)$ & $1(0.9)(1.3)$ & $3(2.8)$ \\
\hline \multicolumn{4}{|l|}{ Acinetobacter pp. } \\
\hline Acinetobacter cloaca & $2(1.9)(6.2)$ & 0 & $2(1.9)$ \\
\hline Acinetobacter bumannii & $1(0.9)(3.1)$ & $4(3.7)(5.3)$ & $5(4.7)$ \\
\hline Acinetobacter Total & $3(2.8)(9.4)$ & $4(3.7)(5.3)$ & $7(6.5)$ \\
\hline \multicolumn{4}{|c|}{ B-G positive Bacteria } \\
\hline Strep pneumonia & 0 & $1(0.9)(1.3)$ & $1(0.9)$ \\
\hline \multicolumn{4}{|l|}{ Staphylococcus species } \\
\hline Staphylococcus aureus & 0 & $5(4.7)(6.8)$ & $5(4.7)$ \\
\hline Staphylococcus hemolyticus & $1(0.9)(3.1)$ & $2(2.6)$ & $3(2.8)$ \\
\hline Staphylococcus epidermedis & $3(2.8)(9.4)$ & $5(4.7)(6.7)$ & $8(7.5)$ \\
\hline Staphylococcus scisuri & 0 & $1(0.9)(1.3)$ & $1(0.9)$ \\
\hline
\end{tabular}




\begin{tabular}{|c|c|c|c|}
\hline Staphylococcus . Total & $4(3.7)(12.5)$ & $13(12.1)(17.3)$ & $17(15.9)$ \\
\hline Enterococcus species & & & $4(3.7)$ \\
\hline Enterococcus faecalis & $1(0.9)(3.1)$ & $3(2.8)(4)$ & $1(0.9)$ \\
\hline Enterococcusfacuim & 0 & $1(0.9)(1.3)$ & $5(4.7)$ \\
\hline Enterococcus Total & $1(0.9)(3.1)$ & $4(3.7)(5.3)$ & $2(1.9)$ \\
\hline C- Organism type isolated & & & $82(76.6)$ \\
\hline Candida & $1(0.9)(3.1)$ & $1(0.9)(1.3)$ & $23(21.5)$ \\
\hline G Negative Bacteria & $26(24.3)(81.25)$ & $56(52.3)(74.7)$ & $107(100)$ \\
\hline
\end{tabular}

\begin{tabular}{|c|c|c|c|c|c|c|}
\hline $\begin{array}{l}\text { 1- Sensitivity test } \\
\text { for E. coli }\end{array}$ & $\begin{array}{c}\text { Ampicillin } \\
\mathrm{No}(\%)\end{array}$ & $\begin{array}{c}\text { Cfotaxime } \\
\text { No(\%) }\end{array}$ & $\begin{array}{c}\text { Gentamycin } \\
\mathrm{No}(\%)\end{array}$ & \multicolumn{3}{|c|}{$\begin{array}{c}\text { Amikacin } \\
\text { No(\%) }\end{array}$} \\
\hline $\mathrm{R}$ & $33(80.5)$ & $21(51.1)$ & $9(22)$ & \multicolumn{3}{|c|}{$9(22)$} \\
\hline $\mathrm{S}$ & $8(19.5)$ & $20(50.9)$ & $32(78)$ & \multicolumn{3}{|c|}{$32(78)$} \\
\hline Total tested & $41(100)$ & $41(100)$ & $41(100)$ & \multicolumn{3}{|c|}{$41(100)$} \\
\hline $\begin{array}{l}\text { 2-Sensitivity test } \\
\text { for for Klebsella } \\
\text { pneumonia }\end{array}$ & $\begin{array}{c}\text { Cefotaxime } \\
\mathrm{No}(\%)\end{array}$ & $\begin{array}{c}\text { Ceftriaxone } \\
\text { No(\%) }\end{array}$ & $\begin{array}{c}\text { Ampicillin } \\
\text { No(\%) }\end{array}$ & $\begin{array}{c}\text { Gentamycin } \\
\text { No(\%) }\end{array}$ & $\begin{array}{l}\text { Amikacin } \\
\mathrm{No}(\%)\end{array}$ & $\begin{array}{l}\text { Ceftazidim } \\
\text { No(\%) }\end{array}$ \\
\hline$R$ & $5(71.4)$ & $6(85.7)$ & $9(90)$ & $7(63.6)$ & $5(41.7)$ & $5(71.4)$ \\
\hline$S$ & $2(28.6)$ & $1(14.3)$ & $1(10)$ & $4(36.4)$ & $7(58.3)$ & $2(28.6)$ \\
\hline Total tested & $7(100)$ & $7(100)$ & $10(100)$ & $11(100)$ & $12(100)$ & $7(100)$ \\
\hline $\begin{array}{l}\text { 3-Sensitivity test } \\
\text { for Pseudomonas }\end{array}$ & amoxicillin & Gentamicin & amikacin & \multicolumn{3}{|c|}{ Cefotaxime } \\
\hline$R$ & $3(100)$ & $4(44.4)$ & $1(10)$ & \multicolumn{3}{|c|}{$4(40)$} \\
\hline$S$ & 0 & $5(55.6)$ & $9(90)$ & \multicolumn{3}{|c|}{$6(60)$} \\
\hline Total tested & $3(100)$ & $9(100)$ & $10(100)$ & \multicolumn{3}{|c|}{$10(100)$} \\
\hline $\begin{array}{c}\text { 5-Sensitivity test } \\
\text { for } \\
\text { Staphylococcus } \\
\text { aureus }\end{array}$ & $\begin{array}{l}\text { Ampicillin } \\
\text { No(\%) }\end{array}$ & $\begin{array}{c}\text { Cefotaxime } \\
\text { No(\%) }\end{array}$ & $\begin{array}{c}\text { Amikacin } \\
\text { No(\%) }\end{array}$ & \multicolumn{3}{|c|}{$\begin{array}{c}\text { Gentamicin } \\
\text { No(\%) }\end{array}$} \\
\hline$R$ & $4(80)$ & $4(80)$ & 0 & \multicolumn{3}{|c|}{$3(60)$} \\
\hline$S$ & $1(20)$ & $1(20)$ & $5(100)$ & \multicolumn{3}{|c|}{$2(40)$} \\
\hline Total tested & $5(100)$ & $5(100)$ & $5(100)$ & \multicolumn{3}{|c|}{$5(100)$} \\
\hline $\begin{array}{l}\text { 5-Drugs sensitivity } \\
\text { test for proteus }\end{array}$ & $\begin{array}{c}\text { Amoxicillin } \\
\mathrm{No}(\%)\end{array}$ & $\begin{array}{c}\text { Ggentamycin } \\
\text { No(\%) }\end{array}$ & $\begin{array}{l}\text { Amikacin } \\
\mathrm{No}(\%)\end{array}$ & \multicolumn{3}{|c|}{$\begin{array}{l}\text { Ceftazidim } \\
\text { No(\%) }\end{array}$} \\
\hline$R$ & $2(100)$ & $2(100)$ & 0 & \multicolumn{3}{|c|}{$1(100)$} \\
\hline$S$ & 0 & 0 & $2(100)$ & \multicolumn{3}{|c|}{0} \\
\hline Total tested & $2(100)$ & $2(100)$ & $2(100)$ & \multicolumn{3}{|c|}{$1(100)$} \\
\hline $\begin{array}{c}\text { 6- Drugs } \\
\text { sensitivity test for } \\
\text { Enterobacter }\end{array}$ & $\begin{array}{c}\text { Ampicillin } \\
\text { No(\%) }\end{array}$ & $\begin{array}{c}\text { Cefotaxime } \\
\text { No(\%) }\end{array}$ & $\begin{array}{c}\text { Ggentamycin } \\
\mathrm{No}(\%)\end{array}$ & \multicolumn{3}{|c|}{$\begin{array}{c}\text { Amikacin } \\
\text { No(\%) }\end{array}$} \\
\hline $\mathrm{R}$ & $7(100)$ & $4(57.1)$ & $4(66.7)$ & \multicolumn{3}{|c|}{$1(16.7)$} \\
\hline $\mathrm{S}$ & 0 & $3(42.9)$ & $2(33.3)$ & & & \\
\hline Total tested & $7(100)$ & $7(100)$ & $6(100)$ & \multicolumn{3}{|c|}{$6(100)$} \\
\hline $\begin{array}{l}\text { 7- Sensitivity test } \\
\text { for Citrobacter }\end{array}$ & $\begin{array}{l}\text { Ampicillin } \\
\mathrm{No}(\%)\end{array}$ & $\begin{array}{c}\text { Ceftriaxone } \\
\text { No(\%) }\end{array}$ & $\begin{array}{c}\text { Ggentamycin } \\
\mathrm{No}(\%)\end{array}$ & \multicolumn{3}{|c|}{$\begin{array}{c}\text { Amikacin } \\
\mathrm{No}(\%)\end{array}$} \\
\hline $\mathrm{R}$ & $2(66.7)$ & $1(33.3)$ & 0 & \multicolumn{3}{|c|}{0} \\
\hline $\mathrm{S}$ & $1(33.3)$ & $2(66.7)$ & $1(100)$ & \multicolumn{3}{|c|}{$3(100)$} \\
\hline Total tested & $3(100)$ & $3(100)$ & $1(100)$ & \multicolumn{3}{|c|}{$3(100)$} \\
\hline $\begin{array}{l}\text { 8-Sensetivity test } \\
\text { fo Enterococcus }\end{array}$ & Ampicillin & Ciprofloxacin & Ggentamycin & \multicolumn{3}{|c|}{ Imipenem } \\
\hline $\mathrm{R}$ & $4(80)$ & $1(20)$ & $3(75)$ & \multicolumn{3}{|c|}{$1(20)$} \\
\hline $\mathrm{S}$ & $1(20)$ & $4(80)$ & $1(25)$ & \multicolumn{3}{|c|}{$4(80)$} \\
\hline Total tested & $5(100)$ & $5(100)$ & $4(100)$ & \multicolumn{3}{|c|}{$5(100)$} \\
\hline $\begin{array}{l}\text { 9- Sensitivity test } \\
\text { for Acinatobacter }\end{array}$ & Ampicillin & Ceftazidime & Cefotaxime & \multicolumn{3}{|c|}{ Gentamycin } \\
\hline $\mathrm{R}$ & $5(83.3)$ & $2(28.6)$ & $1(14.3)$ & & (14.3) & \\
\hline $\mathrm{S}$ & $1(16.6)$ & $5(71.4)$ & $6(85.7)$ & & $85.7)$ & \\
\hline Total tested & $6(100)$ & $7(100)$ & $7(100)$ & & $(100)$ & \\
\hline
\end{tabular}

Table 2 Bacterial sensitivity tests 
Sensitivity test for $E$. coli tests shows that the microorganism is resistant to Ampicillin in (33)80.5\% , Cefotaxime $21(51.1 \%) \quad$ Gentamycin and Amikacin in 9(22\%).Drugs sensitivity test for Klebsella pneumonia shows that the microorganism is resistant to Cefotaxime in 5(71.4\%), Ceftriaxone 6(85.7\%), Ampicillin 9(90\%), Gentamycin $7(63.6 \%)$ Amikacin $5(41.7 \%)$, and to Ceftazidim in 5(71.4\%).

Drugs sensitivity test for Pseudomonas revealed that it is resistant to amoxicillin in $3(100 \%)$, to Gentamicin in $4(44.4 \%)$, to amikacin in $1(10 \%)$, and to Cefotaxime in $4(40 \%)$.Drugs sensitivity test for Staphylococcus aureus revealed that it is resistant to Ampicillin and Cefotaxime in $4(80 \%)$ respectively, to Gentamicin in $3(60 \%)$, and no resistant to Amikacin in $5(100 \%)$ of tested isolates .

Drugs sensitivity test for proteus revealed that it is resistant to amoxicillin and Gentamycine in 2(100\%), respectively, to Ceftazidim in $1(100 \%)$ and no resistant to Amikacin in $2(100 \%)$ of tested isolates .

Drugs sensitivity test for Enterobacter revealed that it is resistant to Ampicillin in $7(100 \%)$, to Cefotaxime in $4(57.1 \%)$ to Ggentamycin in $4(66.7 \%)$ and to Amikacin in $1(16.7 \%)$ of tested isolates .Drugs susceptibility test for citrobacter revealed that it is resistant to Ampicillin in $2(66.7 \%)$, to Ceftriaxone in $1(33.3 \%)$, no resestance to Ggentamycin in $1(100 \%)$ tested isolate and no resestance to Amikacine in $3(100 \%)$ tested isolates .

Drugs susceptibility test fo Enterococcus revealed that it is resistant to Ampicillin in $4(80 \%)$, to Ciprofloxacin in $1(20 \%)$ to Ggentamycin in $3(75 \%)$, and to Imipenem in 1(20\%).Drug sensitivity for Acinatobacter revealed that it is resistant to Ampicillin in 5(83.3\%), to Ceftazidime in $2(28.6 \%)$,to Cefotaxime in $1(14.3 \%)$ and to Gentamycin $1(14.3 \%)$

Discussion : In Arab countries EOS widely ranged from 24 to $74 \%[8]$. Our finding( $29.9 \%$ ) lies within this range indicating that LOS is more predominant that EOS. This agrees with study at Al-Kadimiya teaching hospital in 2010 were 24 cases $(32.9 \%)$ had EOS and 49 cases (67.1\%) cases had LOS.[9] .

Twelve studies from eight Arabic countries including 2308 newborns with culture proven EOS, G negative organisms were the predominant pathogens in Libya, Egypt, Jordan, and Iraq $(65-90 \%$ of all EOS cases[8\}, this agrees with our study where $G$ negative bacteria is constituting $81.25 \%$ while Klebsiella species , Serratia species, Enterobacter species, Escherichia coli, and Pseudomonas species being the most frequent bacteria in Libya, Egypt, Jordan, and previous studies in Iraq[8,10] . E.coli and Klebsella pneumonia are predominant microorganisms in our study. In Baghdad teaching hospital/ medical city[11] it was found(simmilar to our study ) that E. coli was the most common bacteria isolated in 19(23.7\%), followed by Klebsiella pneumoniae16(20\%). In study from Iran K. pneumoniae was the predominant causative bacteria of EOS followed by E. cloacae and E. coli.
In Saudi Arabia, Bahrain and Kuwait, the G-positive microorganisms, coagulase negative Staphylocooci and Staphylococcus aureus were taking the lead (64-75\%)[8], while in our study Staphylocooci constitute $12.5 \%$ of EOS. While in study at al-kadimiya teaching hospital in 2010 staphylococci constitute $46 \%$ of EOS cases these indicates that staphylococci is playing a role in EOS in Iraq in addition to $G$ negative bacteria . Group B Streptococci were the predominant pathogen (24\%) in the United Arab of Emirates (UAE). Candida pp. were emerging in Egypt, UAE, Bahrain, and Kuwait [8]. Low incidence of group B streptococci in this study is similar to the results reported at other hospitals in Iraq and studies in developing countries [12,9,13] In Al Anbar just one case was detected [14] .While in USA still GBS is the most predominant[15]. In medical city Baghdad teaching hospital group B streptococci were $9(11.2 \%)$ [11] , which contradicts other studies in Iraq including our study.

In USA the microorganisms most commonly associated with EOS include the following: Group B Streptococcus (GBS),Escherichia,coli,Coagulase-negative

Staphylococcus ,Haemophilus influenzae ,and Listeria monocytogenes. Trends in the epidemiology of EOS show a decreasing incidence of GBS disease. [15] In Al Anbar Staphylocooci And Klebsiella constitute main microorganisms for LOS[14]. Similar to our study Staphylococci predominate $G$ positive and E.coli predominate $\mathrm{G}$ negative sepsis at Al-Kadimiya teaching hospital in 2010.[9] The study also reveals that $59 \%$ of LOS are due to $\mathrm{G}$ negative and $41 \% \mathrm{G}$ positive bacteria . In our study $\mathrm{G}$ negative bacteria constitute $74.7 \%$ of LOS where E.coli 29(38.7\%), Staphylocooci 13(17.3\%) ,Klebsella pneumonia $8(10.7)$ constitute the most common 3 microorganisms .E.coli is the predominant microorganisim in our study in both EOS and LOS. According to $\mathrm{WHO}$ the most frequent bacteria causing $\mathrm{G}$ negative sepsis in developing countries is E Coli[16].

In developed countries staphylococcus aureus was previously responsible for the majority of late onset infections in many neonatal units with other commonly isolated organisms being coagulase negative staphylococci, E coli, group B streptococcus, Klebsiella pneumoniae, enterococcus, candida and pseudomonas. Coagulase negative staphylococci have now emerged as the leading cause of LOS in almost all developed countries and account for $>50 \%$ of positive blood cultures $[17,18,19]$. An increase in sepsis caused by G-negative organisms has been reported in recent years. [20]. All microorganisms tested shows low sensitivity (highly resistant) to amoxicillin or ampicillin and to gentamycin, this goes with agreement with previous study in this hospital in 2001 on E.coli [21].

For amoxicillin or ampicillin higher resistant (100\%) were encourted with pseudomonas ,proteus and Enterobacter . For cefotaxime the higher rate of resistance (within G negative bacteria) encountered with klebsella ) (71.4\%) compared to $40 \%$ resistant in pseudomonas for the same antibiotic Amikacin also shows varied degree of resistant by E. coli(22\% ) and klebsella(41\%), pseudomonas(10\%) ,and Enterobacter 
(16.7\%) while for Staphylococcus aureus, proteus and citrobacter the sensitivity was $100 \%$ in tested isolates .

Various degrees of antibiotic multi -resistant strains in neonatal sepsis is found in another neonatal unit in Baghdad[9] .

This is in line with data from other studies suggesting high rates of antibiotics resistance among isolates implicated in neonatal sepsis[22,23,24].

This high resistant rate might be due to abuse of $A B$, lack of local policy guidelines and to emerging resistant strains all over the world [25].

Conclusions and recommendations :

$G$ negative bacteria is more common in EOS and LOS with predominant of E. coli in two categories .

Resistant strains to available and commonly used antibiotics is a common finding.

Guidelines in treatment of neonatal sepsis should be frequently reviewed and updated.

Preventive measures for EOS and LOS should be primarily considered.

\section{References}

1. Stoll BJ. Infections of the neonatal infant. In: Nelson Textbook of Pediatrics.Behrman RE, Kleigman RM, Stanton Bf,Schor NF ,etal . 19th ed. Philadelphia: Saunders; 2011:p633.

2. Yang YN, Tseng HI, Yang SN, Lu CC, Chen HL, Chen CJ. A strategy for reduction of antibiotic use in new patients admitted to a neonatal intensive care unit. Pediatr Neonatol 2012;53:245-51.

3. Kumar A,Dutta AK. Recent advances in diagnosis and management of neonatal sepsis in: Infectious Diseases in Children and Newer Vaccines. Jain MP,Yadav SP,Goyal RK etal. India Jaypee Brothers Medical Publishers 2012. P133

4. Bahat BV,kumar M. Neonatal sepses.In: Recent Advances in pediatrics neonatal and pediatric Intensive Care .Gupti S, Gupte SB. V( 21). India. Jaypee Brothers Medical Publishers 2011 p159.

5. Dawodu A, Alumraqn K, Twum-Danso A. A case control study of neonatal sepsis. Experience from Saudi Arabia. Journal of tropical Pediatrics .1997;43:84-8 . 1997;43:84-8 .

6. Clark RH, Bloom BT, Spitzer AR, etal . Empiric use of ampicillin and cefotaxime, compared with ampicillin and gentamycin for neonates at risk for sepsis . Pediatrics . 2006 ; 117:67-74

7. 7- Stoll BJ, Gordon T, Korones SB, Shankaran S, Tyson JE, Bauer CR, et al.Late-onset sepsis in very low birth weight neonates: a report from The National Institute of Child Health and Human Development Neonatal Research Network. The Journal of Pediatrics 1996;129:63-71.

8. Tosson AM, Speer CP. Microbial pathogens causative of neonatal sepsis in Arabic countries. J Matern Fetal Neonatal Med. 2011; 24(8):990-4.

9. Ibrahim SA, Rahma S. Microbiological Profile of Neonatal Septicemia .The Iraqi postgraduate medical journal .2012;11(1) 13-18

10. FahmeySS, Early-onset sepsis in a neonatal intensive care unit in Beni Suef, Egypt: bacterial isolates and antibiotic resistance pattern.Korean $\mathrm{J}$ Pediatr 2013;56(8):332-337

11. Ibraheem MF. Neonatal bacterial sepsis: risk factors, clinical features And short term outcome J Fac Med Baghdad .2011; 53(3) :261- 264

12. Al-Shawi BA, Al-Hadith TS, Al-Abasi AR, etal. Neonatal infection in the neonatal unit at Baghdad Teaching Hospital , Iraq. IPMJ .2006;5:295-97.

13. Payman S, Ali-Akbar R, Massod Y, etal. Neonatal nosocomial infection in Bahrani Children Hospital. Indian J pediatr $2006 ; 78: 197-200$

14. Al-Zwaini EJk neonatal septicaemia in the neonatal care unit ,Al-Anbar governorate ,Iraq .Eastern Mediterranean health journal .2002;8 (4/5):509-514.

15. Klinger G, Levy I, Sirota L, Boyko V, Reichman B, Lerner-Geva L. Epidemiology and risk factors for early onset sepsis among very-low-birthweight infants. Am J Obstet Gynecol. Jul 2009;201(1):38.e1-6.

16. WHO Young Infants Study Group. Bacterial etiology of serious infections in young infants in developing countries. The Pediatric Infectious Disease Journal 1999;18:S17-S22

17. Rubin LG, Sanchez PJ, Siegel J, Levine G, Saiman L, Jarvis WR, Pediatric Prevention Network. Evaluation and treatment of neonates with suspected late onset sepsis: A survey of neonatologists' practices. Pediatrics 2002;110:e42.

18. Isaacs D, Barfield C, Clothier T, Darlow B, Diplock $\mathrm{R}$, Ehrlich $\mathrm{J}$, et al.Late-onset infections of infants in neonatal units. Journal of Paediatrics and Child Health 1996;32: 158-61. [MEDLINE: 97013556; : 9156527]

19. Van den Hoogen A, Gerards LJ, Verboon-Maciolek MA, Fleer A, Krediet TG. Long-Term Trends in the Epidemiology of Neonatal Sepsis and Antibiotic 2009;97(1):22-28.

20. Kristóf K, Kocsis E, Nagy K. Clinical microbiology of early onset and late-onset neonatal sepsis, particularly

among preterm babies. Acta Microbiol Immunol Hung 2009:56;21-51.

21. Baker $H A$,alhashimi $A B$, Althwyni $A N$ Microbiological Study of Escherichia coli O157: H7 Isolated from Bloody Diarrhoea in Children under Ten Years Old. Iraqi Journal of science .2008;49(1):90-94

22. Zaidi A, Huskins C, Tharer D, etal . Hospitalacquired neonatal infections in developing countries . Lancet 02005;365:1175-89

23. Orsin D, Vergnano S, Anthony C. Serious bacterial infections in newborn infant in developing countries . Curr Opin Infec Dis .2004; 17:217-24 .

24. Isaacs D.Unnatural selection :reducing antibiotic resistance in neonatal units. Arch Dis Child Fetal Neonata/Ed 2006;9:F72-4.

25. Arnon S, Litmanovitz I. Diagnostic tests in neonatal sepsis. Curr Opin Infect Dis. Jun 2008;21(3):223-7. 